\title{
Dissolved organic carbon removal by biological treatment
}

\author{
C. Pipe-Martin \\ Ecowise Environmental, Australia
}

\begin{abstract}
Dissolved organic carbon (DOC) is problematic in water recycling or wastewater disposal when it provides precursors for disinfection by-product formation or when it provides a carbon/energy source for microorganisms and biofilms in receiving waters and in distribution systems. Biologically stable water protects receiving waters and recycled water systems. This paper provides initial findings of a research project into optimising DOC removal from water by biological treatment in order to improve its quality and protect public and environmental health. Biological treatment achieves this goal while minimising highly technological and energy intensive processes. The effects of chemical pretreatment, dissolved oxygen, filtration media choice, pre-oxidation and flow rate are reported.

Initial results demonstrate that low flow rate biologically active carbon (BAC) filtration can exhibit biological degradation processes with much higher DOC removal than typically observed in conventional BAC filtration. Results also indicate that the high level of biological activity observed requires aeration to meet oxygen demand and that ozonation improves DOC removal but is not essential for high rate removal. Characterisation of the DOC components removed has been conducted and has identified and quantified the organic compound fractions removed by the biological processes. BAC filtration has the potential to achieve high levels of DOC removal with low energy consumption
\end{abstract} Keywords: DOC removal biological treatment water stability biofilm BAC.

\section{Introduction}

\subsection{Project scope}

There has been enormous growth in the use of recycled water in recent years. At the same time discharge limits for contaminants in wastewater released to 
waterways have decreased. It is essential to develop appropriate technologies for the safe and efficient use of recycled water and minimisation of water pollution. These technologies should also be energy efficient and use appropriate technology for their communities.

Biological treatment of water is widely accepted as one of the first engineered potable water treatment technologies and the bulk of the worlds sewage treatment plants also rely on biological treatment. To date however, the production of high quality recycled water has been primarily performed by physical and chemical processes with the exception of managed aquifer recharge and its associated biological processes. To improve understanding of the potential of biological treatment the Australian Cooperative Research Council for Water Quality and Treatment sponsored the following research into optimising the removal of dissolved organic carbon (DOC) from water by biological processes.

\subsection{Significance of DOC in recycled and discharged water}

In treated sewage effluents or natural waters DOC is a measure of the organic compounds remaining after readily biodegradable compounds have been consumed. This is not to say that DOC in natural and conventionally treated water and wastewater is inert. It still provides a carbon and energy source for bacteria, particularly those living in biofilms. Biofilms occur whenever water is in contact with a solid surface, such as a distribution system pipe. They represent a build up of micro-organisms attached to a surface and embedded in a matrix of microbial organic polymers. Biofilms may also contain inorganic content such as sediment, scale and corrosion deposits. Biofilms provide protection to colonising bacteria from disinfection, while the detachment of cells provides a source of micro-organisms in the overlying water phase.

DOC will also react chemically with disinfecting agents to produce a wide range of by-products. The consequences of biodegradable DOC and resulting biofilms in recycled and waste waters can include:

- loss of residual disinfection in recycled water systems

- reduction of flow in water transport systems

- production of solids as biofilms slough off pipes

- undesirable disinfection by-products

- bacterial growth altering the ecology of receiving water

- anaerobic conditions in transport systems and receiving waters causing death of aquatic organisms and odours

\subsection{Biological treatment techniques}

Current treatment technologies for removing DOC from recycled water are predominantly physical chemical separation processes including enhanced coagulation, nanofiltration, reverse osmosis and ion exchange resins. These processes can very efficiently remove DOC from water but require considerable inputs of capital, energy and operational expertise. Biological treatment processes are typically robust systems that are simple to construct, have low 
energy requirements and are appropriate to the communities they serve. The most common biological water treatment technologies as described by Gimbel, Graham and Collins [1] are slow sand filters, rapid sand filters, biologically active carbon (BAC) filters, river bank filtration and managed aquifer recharge.

\subsection{Project aims}

To further investigate the application of biological water treatment this project focussed on optimising parameters that can be manipulated in constructed treatment units such as rapid and slow sand filters and BAC filters. The parameters investigated include filtration media, dissolved oxygen, contact time, pre-treatment by coagulation/flocculation and the effect of pre-ozonation.

\section{Experimental design}

\subsection{Pilot plant design}

In order to test the operation of biological filters, columns were constructed from PVC pipe with an internal diameter of $237 \mathrm{~mm}$ and mounted vertically to give a total column height of $3.0 \mathrm{~m}$. The base of each column was sealed with a PVC end cap. Outlets were provided at the base, top and at 2 intermediate points in the column. The base of each column was filled with $200 \mathrm{~mm}$ of filter gravel to provide an under drain. All columns with the exception of those used as secondary BAC filters were charged with the required filter media to a depth of $1250 \mathrm{~mm}$. Secondary BAC filters had a filter media depth of $550 \mathrm{~mm}$.Each column was provided with feed water from the top. Feed water was supplied from sample lines on the treatment plant hosting the pilot columns. A constant head of $1400 \mathrm{~mm}$ was provided to the filters. Filter materials used were washed filter sand, granular activated carbon (GAC) and a patented polyethene bioreactor media. Flow through the columns was controlled by a valve on the outlet of the filters. An aeration system of coarse bubblers was provided to the head of the filter columns.

\subsection{Feed water and pre-treatments}

The South Caboolture Water Reclamation Plant hosted six filter columns. Feed streams used were secondary sewage treatment effluent, effluent treated by flocculation/filtration and effluent treated by flocculation/filtration and then ozonated. A summary of the filter configurations is found in table 1 .

By employing this configuration of filter materials and feed waters it was possible to concurrently run a number of experiments. Experiment 1 compared the effect of pre-treatments using columns 1,2 and 3. Experiment 2 compared the effect of filtration media using columns 2, 4 and 6. Experiment 3 investigated the effect of ozonation on performance of BAC filters using columns 2 and 3 as well as 4 and 5. Experiment 4 evaluated the effect of contact time on all columns. 
Table 1: $\quad$ SCWRP trial filters.

\begin{tabular}{|l|l|l|l|l|l|l|}
\hline & $\begin{array}{l}\text { Column } \\
1\end{array}$ & $\begin{array}{l}\text { Column } \\
2\end{array}$ & $\begin{array}{l}\text { Column } \\
3\end{array}$ & $\begin{array}{l}\text { Column } \\
4\end{array}$ & $\begin{array}{l}\text { Column } \\
5\end{array}$ & $\begin{array}{l}\text { Column } \\
6\end{array}$ \\
\hline media & sand & sand & sand & GAC & GAC & PE \\
\hline Feed & $\begin{array}{l}\text { STP } \\
\text { effluent }\end{array}$ & $\begin{array}{l}\text { STP } \\
\text { effluent }\end{array}$ & $\begin{array}{l}\text { STP } \\
\text { effluent }\end{array}$ & $\begin{array}{l}\text { STP } \\
\text { effluent }\end{array}$ & $\begin{array}{l}\text { Column 3 } \\
\text { outlet }\end{array}$ & $\begin{array}{l}\text { STP } \\
\text { effluent }\end{array}$ \\
\hline $\begin{array}{l}\text { Pre- } \\
\text { treatment }\end{array}$ & $\begin{array}{l}\text { No Pre- } \\
\text { treatme } \\
\text { nt }\end{array}$ & $\begin{array}{l}\text { Alum } \\
\text { DAFF }\end{array}$ & $\begin{array}{l}\text { Alum } \\
\text { DAFF } \\
\text { ozone }\end{array}$ & $\begin{array}{l}\text { Alum } \\
\text { DAFF }\end{array}$ & $\begin{array}{l}\text { Alum } \\
\text { DAFF } \\
\text { ozone } \\
\text { Bio sand }\end{array}$ & $\begin{array}{l}\text { Alum } \\
\text { DAFF }\end{array}$ \\
& & & & \\
\hline
\end{tabular}

\subsection{Analytical methods}

Key parameters were routinely monitored in situ on the inlet and outlet of trial columns using a YSI multiparameter sonde fitted with sensors for $\mathrm{pH}$, dissolved oxygen, temperature and salinity. Samples were taken for parameters that could not be measured in situ. Samples were tested for DOC and UV absorbance at $254 \mathrm{~nm}$. DOC was determined on membrane filtered samples by the high temperature furnace method using an OI1020A organic carbon analyser. UV absorbance was determined on membrane filtered samples using a Varian Cary $50 \mathrm{UV}$ visible spectrophotometer.

\section{Results and discussion}

\subsection{Establishment of biological action}

Feed water flow was initiated in December 2006. Dissolved oxygen consumption was measured at regular intervals as an indicator of biological activity. Within 1 week of flow commencing significant DO decrease across the columns indicated biological activity had commenced. Routine measurement of DOC, UV254 abs and DO was used to track the progress of the columns. During the initial phase of operation, high DOC and UV254 decreases were observed in the GAC columns due to physical adsorption onto the media. By the start of August 2007 DOC and UV254 removal had stabilised indicating a steady state biological process was established.

\subsection{Dissolved oxygen}

Dissolved oxygen was measured for all columns in the head water and in the water leaving the filter column. Within the first week it became apparent that the DO content of the feed waters would be a limiting factor for biological treatment. An air supply was installed through a coarse bubble outlet to increase DO in the head water. The air supply also provided air lift mixing, which ensured the head water was well mixed. DO consumption up to $5.4 \mathrm{mg} / \mathrm{L}$ has been observed on sand media columns and up to $7.1 \mathrm{mg} / \mathrm{L}$ on activated carbon columns. Low DO saturation levels during high ambient temperatures can limit 
aerobic biological activity even when using pre-aeration. Filter outlet DO has been recorded lower than $1 \mathrm{mg} / \mathrm{L}$ during high temperature periods.

\subsection{Media}

Filter media was found to have a major effect on the level of biological activity observed and subsequent DOC removal. Typical DOC removal and DO consumption for the same feed water in similar conditions is demonstrated in table 2. The feedwater was coagulated/filtered effluent with flow rate of $0.9 \pm 0.1 \mathrm{~m} / \mathrm{hr}$ and a temperature of $27.6 \pm 0.1^{\circ} \mathrm{C}$.

Table 2: $\quad$ Effect of media on biological activity.

\begin{tabular}{|l|l|l|}
\hline Column media & DO decrease $\mathrm{mg} / \mathrm{L}$ & DOC decrease $\mathrm{mg} / \mathrm{L}$ \\
\hline Sand & 2.8 & 1.8 \\
\hline Activated carbon & 6.9 & 2.7 \\
\hline Polythene & 2.0 & 0.9 \\
\hline
\end{tabular}

The polyethene media performed poorly during the first year of operation. There is evidence that DOC removal is slowly increasing as biofilm growth continues in the internal spaces of the media. Sand columns removed up to $25 \%$ DOC. Activated carbon removed up to $45 \%$ DOC after stabilisation and typically had twice the removal capability of sand media under similar conditions.

\subsection{Pre-ozonation}

The effect of ozonation on biological removal of DOC was assessed by comparing the results from a sand media column fed with coagulated filtered water and a similar column fed by coagulated filtered water which had also been ozonated at a dose of $5 \mathrm{mg} / \mathrm{L}$. Typical results are shown in table 3 . The feedwater flow rate was $0.82 \pm 0.03 \mathrm{~m} / \mathrm{hr}$ at a temperature of $22.5 \pm 0.1^{\circ} \mathrm{C}$.

Table 3: $\quad$ Effect of ozonation on biological activity of sand filters.

\begin{tabular}{|l|l|l|}
\hline feedwater & $\begin{array}{l}\text { DO decrease } \\
\mathrm{mg} / \mathrm{L}\end{array}$ & $\begin{array}{l}\text { DOC decrease } \\
\mathrm{mg} / \mathrm{L}\end{array}$ \\
\hline Coagulated/filtered & 3.2 & 1.6 \\
\hline Coagulated/filtered/ozonated & 3.3 & 2.3 \\
\hline
\end{tabular}

The effect of ozonation was also assessed by comparing a BAC filter fed with non ozonated water with a combined sand BAC column fed with ozonated water. The BAC depth of the filters varied, however, by comparing results at similar BAC contact times a meaningful comparison of DOC removal can be made. The results in table 4 are for a BAC empty bed contact time of $43 \pm 7$ minutes at a temperature of $22.0 \pm 0.5^{\circ} \mathrm{C}$.

Although ozonation significantly increased DOC removal the size of the increase was less than was expected. A comparison of the DOC remaining after treatment processes is shown in figure 1 . 
Table 4: $\quad$ Effect of ozonation on biological activity of BAC filters.

\begin{tabular}{|l|l|l|}
\hline Feedwater & $\begin{array}{l}\text { DO decrease } \\
\mathrm{mg} / \mathrm{L}\end{array}$ & $\begin{array}{l}\text { DOC decrease } \\
\mathrm{mg} / \mathrm{L}\end{array}$ \\
\hline Coagulated/filtered & 6.6 & 3.4 \\
\hline Coagulated/filtered/ozonated & 8.3 & 4.3 \\
\hline
\end{tabular}

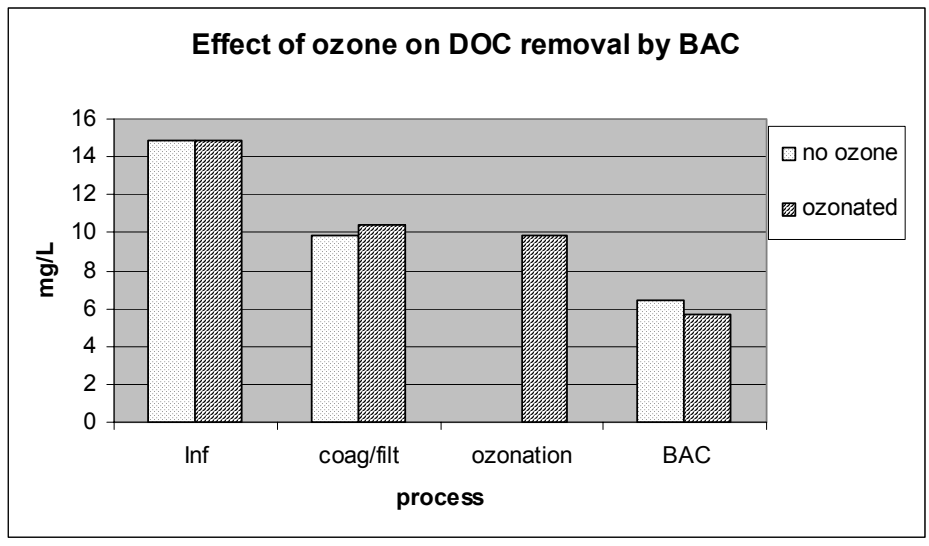

Figure 1: Ozonation effect on DOC removal by BAC.

\subsection{Contact time}

DOC removal by the columns was assessed at varying flow rates over an eight day period with stable weather, temperature and column conditions. Contact time was expressed as Empty Bed Contact Time (EBCT). As expected increasing EBCT increases DOC removal. DOC removal in BAC beds was found to

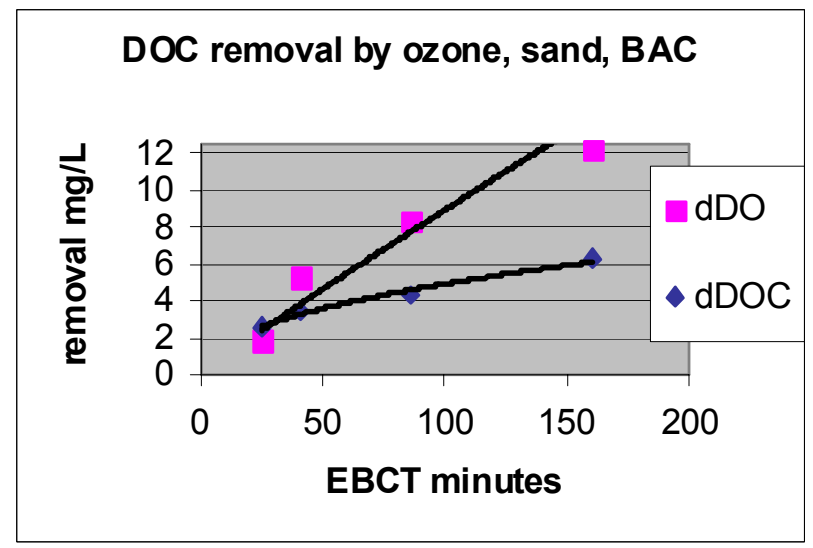

Figure 2: $\quad$ Effect of flow rate on DOC removal and biological activity. 
continue to increase at contact times in excess of those typically used for BAC filtration. The effect of flow rate is demonstrated in figure 2 .

\subsection{Fractions removed}

To help characterise the effects of biological treatment it is useful to separate the compounds present and their contribution to DOC into classes with similar functionality. This can be achieved by rapid resin fractionation technique of Chow et al. [2]. DOC is separated into four fractions identified as very hydrophobic acids (VHA), slightly hydrophobic acids (SHA), hydrophilic charged compounds (CHA) and hydrophilic neutral compounds (NEU). Fractionation results for the test columns are summarised in table 5. The major DOC fractions in the treated wastewater tested were the hydrophobic acids. A large amount of the hydrophobic fractions is removed by alum flocculation. Of the remaining VHA fraction $10 \%$ is removed by biological sand filtration, $47 \%$ by BAC filtration and $62 \%$ by ozone BAC treatment. Of the remaining SHA fraction $15 \%$ is removed by biological sand filtration $25 \%$ by BAC filtration and $40 \%$ by ozone BAC treatment. Removal of the hydrophilic and neutral fractions is minor.

Table 5: $\quad$ DOC fractionation results.

\begin{tabular}{|l|l|l|l|l|l|}
\hline Treatment processes & $\begin{array}{l}\text { VHA } \\
\mathrm{mg} / \mathrm{L}\end{array}$ & $\begin{array}{l}\text { SHA } \\
\mathrm{mg} / \mathrm{L}\end{array}$ & $\begin{array}{l}\text { CHA } \\
\mathrm{mg} / \mathrm{L}\end{array}$ & $\begin{array}{l}\text { NEU } \\
\mathrm{mg} / \mathrm{L}\end{array}$ & $\begin{array}{l}\text { Total } \\
\text { removal }\end{array}$ \\
\hline Secondary effluent & 7.5 & 2.9 & 1.3 & 1.1 & na \\
\hline floc/filtration & 4.0 & 2.0 & 0.8 & 0.9 & $40 \%$ \\
\hline floc/filtn, biosand & 3.6 & 1.7 & 0.7 & 0.7 & $48 \%$ \\
\hline floc/filtn, BAC & 2.1 & 1.5 & 0.8 & 0.5 & $62 \%$ \\
\hline floc/filtn, ozone/BAC & 1.5 & 1.2 & 0.6 & 0.5 & $78 \%$ \\
\hline
\end{tabular}

\section{Conclusions}

\subsection{Media}

Activated carbon is clearly the preferred media for biological filtration and removal of DOC. The large surface area of activated carbon along with the ability of DOC to bind organic compounds until they are biodegraded means that BAC filters achieve much higher DOC removal than sand or artificial media.

\subsection{Pretreatment}

Alum flocculation and rapid sand filtration directly removes DOC and allows very long filter runs, which facilitate stable biological activity of the filters. Ozonation will increase the DOC removal possible by BAC filtration however the cost and complexity of ozone dosing may not be justified by the increase in removal achieved. Aeration of feed water is essential to achieve the high DOC 
removal exhibited by the test columns with the exception of ozonated systems which supersaturate water with DO.

\subsection{Contact time}

The contact time required for high removal of DOC from pre-treated waste water will depend on the characteristics of the water being treated but is higher than that typically used in BAC filtration. For the treated domestic waste water used for this project an EBCT of 60 minutes eliminated $70 \%$ of the DOC removable biologically. Virtually all biologically treatable DOC was removed by an EBCT of 200 mins.

\subsection{Biological filter configurations}

The test filters using coagulated/ filtered water feeds have achieved extremely long run times of 3 to 4 months. The long run time enables the use of a slow filter configuration. Alternatively $\mathrm{BAC}$ is usually used in a rapid filter configuration with the convenience of backwashing for filter cleaning. To achieve the DOC removal demonstrated, rapid filters require much longer than usual contact and run times.

\subsection{Applications}

Use of BAC filters has been demonstrated as a viable technology for removing DOC from waste water streams to produce biologically stable water with reduced potential for bio-fouling of pipes and fittings. The treated water has fewer organic compounds to act as precursors for disinfection by-product formation. As a result the use of biological treatment processes with high DOC removal has the potential for improved outcomes where:

- Beneficial reuse of water is required for high level uses

- Reuse water is transported over long distances or stored for extended periods

- Disinfectant demand in water is high and residual disinfection is short lived

- Disinfection by-products are of concern

- Treated waste water is discharged into highly sensitive receiving waters

\section{References}

[1] Gimbel R., Graham N., Collins R. (Eds). Recent Advances in Slow Sand and Alternative Biofiltration Processes, IWA Publishing: London, 2006.

[2] Chow, C., Fabris, R., Drikas, M., A Rapid Fractionation Technique to Characterise Natural Organic Matter for the Optimisation of Water Treatment Processes. J Water SRT - Aqua 52, (7), pp 475-487, 2003. 